\title{
Correction: Brown, K., et al. Diet-Induced Dysbiosis of the Intestinal Microbiota and the Effects on Immunity and Disease. Nutrients 2012, 4, 1095-1119
}

\author{
Kirsty Brown $^{\dagger}$, Daniella DeCoffe ${ }^{\dagger}$, Erin Molcan and Deanna L. Gibson * \\ Department of Biology, University of British Columbia Okanagan, Kelowna, BC V1V 1V7, Canada; \\ E-Mails: kirsty.brown12@gmail.com (K.B.); ubcpeermentor.daniella@gmail.com (D.D.); \\ erinmolcan@gmail.com (E.M.)
}

$\dagger$ These authors contributed equally to this work.

* Author to whom correspondence should be addressed; E-Mail: deanna.gibson@ubc.ca; Tel.: +1-250-807-8790; Fax: +1-250-807-8005.

Received: 17 October 2012 / Accepted: 23 October 2012 / Published: 26 October 2012

We have found following errors in paper [1] which has been published in Nutrients, the following references should be cited as:

71. Turnbaugh, P.J.; Hamady, M.; Yatsunenko, T.; Cantarel, B.L.; Duncan, A.; Ley, R.E.; Sogin, M.L.; Jones, W.J.; Roe, B.A.; Affourtit, J.P.; et al. A core gut microbiome in obese and lean twins. Nature 2009, 457, 480-484.

72. Ley, R.E.; Turnbaugh, P.J.; Klein, S.; Gordon, J.I. Microbial ecology: Human gut microbes associated with obesity. Nature 2006, 444, 1022-1023.

73. Duncan, S.H.; Lobley, G.E.; Holtrop, G.; Ince, J.; Johnstone, A.M.; Louis, P.; Flint, H.J. Human colonic microbiota associated with diet, obesity and weight loss. Int. J. Obes. (Lond.) 2008, 32, 1720-1724.

74. Million, M.; Angelakis, E.; Paul, M.; Armougom, F.; Leibovici, L.; Raoult, D. Comparative meta-analysis of the effect of lactobacillus species on weight gain in humans and animals. Microb. Pathog. 2012, 53, 100-108.

75. Karlsson, C.L.; Onnerfalt, J.; Xu, J.; Molin, G.; Ahrne, S.; Thorngren-Jerneck, K. The microbiota of the gut in preschool children with normal and excessive body weight. Obesity (Silver Spring) 2012, doi:10.1038/oby.2012.110. 
76. Cani, P.D.; Bibiloni, R.; Knauf, C.; Waget, A.; Neyrinck, A.M.; Delzenne, N.M.; Burcelin, R. Changes in gut microbiota control metabolic endotoxemia-induced inflammation in high-fat diet-induced obesity and diabetes in mice. Diabetes 2008, 57, 1470-1481.

77. Million, M.; Maraninchi, M.; Henry, M.; Armougom, F.; Richet, H.; Carrieri, P.; Valero, R.; Raccah, D.; Vialettes, B.; Raoult, D. Obesity-associated gut microbiota is enriched in Lactobacillus reuteri and depleted in Bifidobacterium animalis and Methanobrevibacter smithii. Int. J. Obes. (Lond.) 2012, 36, 817-825.

124. Belluzzi, A. Polyunsaturated fatty acids ( $n-3$ PUFAs) and inflammatory bowel disease (IBD): Pathogenesis and treatment. Eur. Rev. Med. Pharmacol. Sci. 2004, 8, 225-229.

We would like to apologize for any inconvenience caused to our readers.

\section{Reference}

1. Brown, K.; Decoffe, D.; Molcan, E.; Gibson, D.L. Diet-induced dysbiosis of the intestinal microbiota and the effects on immunity and disease. Nutrients 2012, 4, 1095-1119.

(C) 2012 by the authors; licensee MDPI, Basel, Switzerland. This article is an open access article distributed under the terms and conditions of the Creative Commons Attribution license (http://creativecommons.org/licenses/by/3.0/). 